\title{
ORIGINALISM AND ITS DISCONTENTS (PLUS A THOUGHT OR TWO ABOUT ABORTION)
}

\author{
Mitchell N. Berman*
}

In Abortion and Original Meaning, ${ }^{1}$ Jack Balkin presents an intriguing new argument for the soundness of the result, though not the reasoning, of Roe v. Wade. ${ }^{2}$ Balkin is one of his generation's widest ranging and most consistently engaging legal theorists, and his analyses of the original principles undergirding the Fourteenth Amendment and how they bear on the debate over abortion is characteristically thought-provoking. But they are offered in service of a "larger purpose"-namely, "to demonstrate why the debate between originalism and living constitutionalism rests on a false dichotomy." Once we "reject the assumption that fidelity to the [constitutional] text means fidelity to original expected application," Balkin contends, we ought instead to agree that "constitutional interpretation requires fidelity to the original meaning of the Constitution and to the principles that underlie the text." In maintaining such fidelity, however, "[e]ach generation makes the Constitution their Constitution by calling upon its text and its principles and arguing about what they mean in their own time." It follows, Balkin claims, that "[t]he choice between original meaning and living constitutionalism ... is a false choice."

* Bernard J. Ward Centennial Professor in Law. The University of Texas at Austin. E-mail: mberman@law.utexas.edu. (2007).

1. Jack M. Balkin. Abortion and Original Meaning, 24 CONST. COMMENT. 291

2. 410 U.S. $113(1973)$.

3. Balkin. supra note 1. at 292.

4. Id. at 293 .

5. Id. at 301 .

6. Id. at 293: see also id. at 306 ("The tradition of continuous arguments about how best to implement constitutional meaning in our own time produces changes in constitutional doctrines, practices, and law. That is why. ultimately, there is no conflict between fidelity to text and principle and practices of constitutionalism that evolve over time."). 
I believe that Balkin mischaracterizes contemporary originalism. Although Justice Scalia constitutes a striking-but possibly only partial-counter-example, an overwhelming number of contemporary constitutional theorists who actively defend originalism have already rejected the assumption that Balkin asks them to reject. While there does exist a live intramural disagreement among originalists concerning whether to abide by the originally intended meaning of the framers (or ratifiers) of constitutional text or the text's original public meaning, almost nobody espouses fidelity to the originally expected applications.

More important, though, is what follows once we all reject what Ronald Dworkin dubbed "expectation originalism." Balkin's conclusion that originalism and non-originalism present a false choice rests squarely on his argument that fidelity to the Constitution requires fidelity to its original meaning and precludes contemporary interpreters from interpreting its text in accordance with other principles that the text can bear. ${ }^{8}$ But nonoriginalists simply do not agree that fidelity to the Constitution requires fidelity to the original meaning "and the principles $i t$ was designed to enact." And nothing in Balkin's article, I will argue, should convince them that what they see as a true choice is in fact a false one. In short, then, Abortion and Original Meaning is unlikely to make anybody happy: Its empirical claims about the state of originalist argumentation are apt to gall the originalists, while its normative (or perhaps conceptual) claims about what constitutional interpretation requires will fail to move the non-originalists. Part I of these remarks argues that theorists in both camps have reason to be dissatisfied.

Of course, even if Balkin's claims about interpretive theory fail, his narrower arguments about abortion rights might nonetheless succeed. Unfortunately, I do not believe that Balkin offers us a sounder basis upon which to rest the conclusion that legislative prohibition of abortion is unconstitutional. Part II briefly explains why.

7. Ronald Dworkin. Comment, in A MATTER OF INTERPRETATION: FEDERAL COURTS AND THE LAW 115, 119 (Amy Gutman ed., 1997).

8. See, e.g., Balkin, supra note 1, at 303 ("We look to underlying principles because when the text uses relatively abstract and general concepts, we must know which principles the text presumes or is attempting to embrace. If we read the text to presume or embrace other principles, then we may be engaged in a play on words and we will not be faithful to the Constitution's purposes.").

9. Id. at 293 (emphasis added). 


\section{ORIGINALISM AND LIVING CONSTITUTIONALISM}

\section{A. EXPECTATION ORIGINALISM: NOT A TRUE OPPONENT}

According to Balkin, self-described originalists, along with their adversaries, believe that expected applications of constitutional provisions are binding on present-day interpreters. This, he argues, is an unsatisfactory view. I agree. ${ }^{10}$ The question, though, is whether it's a live one. After all, the view was addressed at length a decade ago - and, I would have thought, demolished-in an important article by Mark Greenberg and Harry Litman. ${ }^{11}$ As they explained, "original meaning, properly understood, must contemplate the possibility that a traditional practice is unconstitutional." ${ }^{12}$ In part, this is because, as they argued with care, "requiring fidelity to original practices is inconsistent with interpreting constitutional provisions to stand for principles." ${ }^{\prime 3}$ Not surprisingly, then, leading academic defenders of originalism have been disavowing expectation originalism for years. Writing just last year in the Yale Law Journal, for example, Michael Paulsen protested that it is "a caricature of originalism" to portray it as "a version of crude intentionalism that focuses on the specific subjective intentions or expectations of individuals as to how a provision might be applied." ${ }^{14}$ Michael McConnell was even more blunt. "[N]o reputable originalist, with the possible exception of Raoul Berger, takes the view that the Framers' 'assumptions and expectations about the correct application' of their principles is controlling," he argued a decade ago. "Mainstream originalists recognize that the Framers' analysis of particular applications could be wrong, or that circumstances could have changed and made them wrong."

10. I am disinclined, however, to second Balkin's claim that " $t \mathrm{t}]$ he basic problem with looking to original expected application for guidance is that it is inconsistent with so much of our existing constitutional traditions." Balkin, supra note 1 , at 297 . I am disposed, rather, to think that the most formidable objection to expectation originalism is grounded in our best understanding of the logical structure of constitutional adjudication. But that's another story.

11. Mark D. Greenberg \& Harry Litman, The Meaning of Original Meaning, 86 GEO. L.J. 569 (1998)

12. Id. at $570-71$.

13. Id. at 571 .

14. Michael Stokes Paulsen, How To Interpret the Constitution (and How Not To), 115 YALE L.J.. 2037, 2059 (2006).

15. Michael W. McConnell. The Importance of Humility in Judicial Review: A Comment on Ronald Dwokin's "Moral Reading" of the Constitution, 65 FORD. L. REV. 1269. 1284 (1997). 
Swimming against this tide ${ }^{16}$ Balkin asserts loosely that "[o]riginalists generally assume that if we do not apply the constitutional text in the way it was originally understood at the time of its adoption we are not following what the words mean and so will not be faithful to the Constitution as law," and that "they have tended to conflate two different ideas-the expected application of constitutional texts, which is not binding law, and the original meaning, which is." ${ }^{17}$ "Many originalists," he adds, "have encouraged this conflation ... [and] living constitutionalists too have mostly accepted this conflation without question." But the evidence offered of this supposed general assumption and tendency toward conflation is sparse. In fact, the only originalist theorist Balkin discusses at any length is Justice Scalia who, says Balkin, "insists that the concepts and principles underlying [the constitutional text] must be applied in the same way that they would have been applied when they were adopted."

As I read him, Scalia's relationship to expectation originalism is more complex. In response to Dworkin's distinction between semantic and expectation originalism, after all, Scalia did expressly avow his allegiance to the original public meaning of the constitutional text and disavow fidelity to "the concrete expectations of lawgivers. ${ }^{\prime 20}$ On the other hand, Balkin is surely correct that much of Scalia's writing, both academic and judicial, does appear to endorse and rely upon the expectation originalism that he purports to reject. Because Scalia's efforts to explain away the apparent disparity ring, to me at least, rather false, ${ }^{21}$ de-

16. See also, e.g., Randy E. Barnett. An Originalism for Nonoriginalists, 45 LoYOLA L. REV. 611. 622 (1999) (endorsing Dworkin's distinction between "semantic" and "expectations" originalism. and explaining that the new brand of originalists are unconcerned with "how the relevant generation of ratifiers expected or intended their textual handiwork would be applied to specific cases... except as circumstantial evidence of what the more technical words and phrases in the text might have meant to a reasonable listener"): Eric J. Segall. A Century Lost: The End of the Originalism Debate, 15 CONST. COMMENT. 411. 429-32 (1998) (arguing that no contemporary originalists endorse expectation originalism).

17. Balkin, supra note 1 , at 292

18. Id. at $292-93$.

19. Id. at 295 .

20. Antonin Scalia, Response, in A MATTER OF INTERPRETATION, supra note 7, at 129.144.

21. The most often noted example of Scalia's seeming attachment to expectation originalism - remarked on by both Dworkin and Laurence Tribe in their separate comments on Scalia's Tanner Lecture - is his view that capital punishment cannot run afoul of the Eighth Amendment's ban on cruel and unusual punishments because it is contemplated elsewhere in the constitutional text. See Antonin Scalia, Common-Law Courts in a Civil-Law System: The Role of United States Federal Courts in Interpreting the Constitution and Laws, in A MATTER OF INTERPRETATION, supra note 7. at 3, 46; Antonin 
termining how best to make sense of Scalia's conflicting signals is no mean feat. ${ }^{22}$ I won't try. Despite my quibbling, then, I'm content for present purposes to accept Balkin's description of Scalia as a proponent of expectation originalism.

But even granting Scalia, who else? As best I could tell, Balkin cites only three other proponents of the expectation originalism that is his target - Robert Bork, Raoul Berger, and Clarence Thomas. ${ }^{23}$ Frankly, I am uncertain about Berger and Thomas; we are not favored with page citations or parentheticals that might either substantiate Balkin's claim or at least help us to assess it. ${ }^{24}$ But the inclusion of Bork on this list strikes me as mis-

Scalia. Originalism: The Lesser Evil. 57 U. CiN. L. REV. 849. 863 (1989): Laurence H. Tribe. Comment. in A MATTER OF INTERPRETATION. supra note 7, at 65. 66; Dworkin, supra note 7 , at 120 .

Scalia s response to the objection that his argument here seems to be expectationist is to describe the original meaning of the relevant part of the Eighth Amendment as a bar to the infliction of punishments that "we consider cruel today." Scalia, supra note 20, at 145. If that was the original public meaning. then the endorsement of capital punishment in the Fifth Amendment's Due Process. Double Jeopardy, and Grand Jury Clauses is simply evidence-very powerful evidence to be sure, but evidence only - that the death penalty does not fall within the extension of the concept of what Americans considered cruel in 1791 .

What makes this explanation unpersuasive, in my view, is the premise that the original public meaning of "cruel" was "what we consider cruel today" rather than, well, "what is cruel." Such a premise must be predicated. I think. on the view that the Constitution (or at least the Eighth Amendment) does not constitutionalize moral principles as such but only the ratifying generation's understanding of the moral principle. And that this is indeed Scalia's view is suggested by his reference to "the moral perceptions of the time." Id. (emphases added and omitted).

To be sure. this could have been the original meaning of the text. But it is hardly the text's most natural or obvious rendering. Moreover. Scalia seems to forget himself when concluding. in the very next sentence, that, in light of the Fifth Amendment, "it is entirely clear that capital punishment. which was widely in use in 1791 , does not violate the abstract moral principle of the Eighth Amendment." Id. So which is it: the Eighth Amendment purports to (was understood to) constitutionalize an abstract moral principle or it purports to (was understood to) constitutionalize society's beliefs about moral principles? That Scalia cannot have it both ways should be apparent to a moral realist. But I don't think that even moral anti-realism offers a way out. While anti-realists of some stripes would indeed maintain that an attempt to constitutionalize a moral principle can only amount to constitutionalization of the society's beliefs about moral principles, it does not follow that this truth forms any part of the content of the public understanding of the relevant text. Put another way. the public meaning or understanding of a text that purports to constitutionalize a moral principle is likely to include reference to society's beliefs about the supposed moral principle only in a society of anti-realists.

22. For further evidence of Scalia's inconsistencies on this question see Segall, supra note 16 . at $427-29$.

23. See Balkin. supra note 1. at 295 n.9.

24. Balkin's evidence for including Thomas among the small number of expectation originalists is a seven-page lecture published over a decade ago. Clarence Thomas, Judging, 45 U. KAN. L. REV. 1 (1996). For myself. I see nothing in the speech that suggests expectation originalism. and perhaps some evidence to the contrary. See id. at 5-6 ("When it comes time to interpret the Constitution's provisions, such as, for instance. the 
taken - and revealingly so. Of the two pages in The Tempting of America to which Balkin draws our attention, one (page 159) has no obvious bearing on the question at all. And on the other page (144) Bork's point is solely to make clear, in the face of apparently conflicting views he had expressed two decades earlier, that he espouses original meaning originalism over original intent originalism; that is, he favors the original public meaning of the text over the subjective semantic intentions of any specific individuals. But this is not to espouse fidelity to the original expectations the framers or ratifiers might have had about how the textual meaning would apply.

Were there any real doubt about this, consider Bork's famously unpersuasive effort to establish that Brown v. Board of Education is consistent with originalism. That argument, most readers will recall, runs like this: the original understanding of the Equal Protection Clause incorporated the principle of "equality" or "equality before the law"; the ratifiers believed or assumed that racial segregation was consistent with such equality; and, when the inconsistency became apparent, the Court properly gave effect to the originally understood principle and not to the originally expected, though mistaken, application of that principle. ${ }^{25}$ Whatever the argument's faults, ${ }^{26}$ it rests squarely on Borks rejection of expectation originalism and his endorsement of something very much like the meaning-andprinciple originalism that Balkin favors-though admittedly without Balkin's emphasis on the plasticity, contestability or fluidity of underlying principles.

Perhaps Balkin is misled into thinking that expectation originalism is more widespread than it is by his view that "[w]hen people use the term 'original understanding,' and sometimes even 'original meaning'-as Scalia does-they are actually talking about original expected application.,"27 Again, the basis

Speech or Press Clauses of the First Amendment, reasonable minds can certainly differ as to their exact meaning. But that does not mean that there is no right or correct answer: that there are no clear. eternal principles recognized and put into motion by our founding documents.") (emphasis added).

25. See Robert H. Bork. The Tempting of america: The Political SEDUCTION OF THE LAW 81-83 (1990).

26. The most glaring fault is that Bork renders the original understanding at such a high level of generality-"equality" and "equality before the law"-as to sacrifice originalism's pretensions to serious historical inquiry and its promise to impose meaningful constraints on judges.

27. Balkin, supra note 1 , at 296. 
for this claim escapes me; indeed, I think the claim is unlikely to be true.

For a keen illustration, consider how Justice Scalia analyzed the question, raised in Minnesota $v$. Dickerson, ${ }^{28}$ of whether the Fourth Amendment permits police to seize contraband detected during a Terry frisk. ${ }^{29}$ After insisting that "the terms in the Constitution must be given the meaning ascribed to them at the time of their ratification," ${ }^{30}$ Scalia proceeded to recognize that the scope of the application of those terms could change. "[E]ven if a 'frisk' prior to arrest would have been considered impermissible in $1791 \ldots$ perhaps it is only since that time that concealed weapons capable of harming the interrogator quickly... have become common-which might alter the judgment of what is 'reasonable' under the original standard., ${ }^{31}$ Here, original meaning is expressly distinguished from original expected application.

Or take the constitutional grounds for impeachment: "treason, bribery, or other high crimes and misdemeanors." 32 One who emphasizes that we should follow the 1789 meaning of the word misdemeanor-serious wrongdoing-and not its current meaning-minor offense-would be most unlikely to think a president impeachable for all and only those offenses that were considered serious in 1791 . To the contrary, as to any conduct (oh, I don't know-adultery?) that would have been considered a misdemeanor in 1789 under the 1789 definition and that is considered a misdemeanor in 2007 under the 2007 definition-i.e., some conduct that was deemed to be serious wrongdoing in 1789 but is only a petty offense today - the point of advocating fidelity to the "original meaning" or "original understanding" is precisely to oppose acting in accordance with the "original expected application."

Balkin declares portentously that " $[t]$ he concepts embodied by the words of constitutional text and the principles underlying the text, and not their original expected application, are the central concern of constitutional interpretation." ${ }^{33}$ My point thus far is that it would be hard to find an originalist who would dissent.

28. 508 U.S. 366 (1993).

29. This very helpful illustration was (as far as I know) initially provided in Lawrence Lessig, Understanding Changed Readings: Fidelity and Theory, 47 STAN L. REV. 395, 398-99 (1995), and reintroduced in Segall. supra note 16, at 428-29.

30. 508 U.S. at 379 (Scalia, J.. concurring).

31. Id. at 382 .

32. U.S. CONST. art. II, $\$ 4$.

33. Balkin, supra note 1 , at 302. 


\section{B. BALKINIAN ORIGINALISM AND LIVING \\ CONSTITUTIONALISM: NOT A FALSE CHOICE}

Conceivably, one could respond to this objection by marshaling more evidence to support the empirical proposition that many theorists of originalism do in fact espouse expectation originalism. Such a showing would surprise me but would scrape no skin off my own, non-originalist, nose. But Balkin is more likely, I think, to deflect the objection by insisting that it targets a matter of only minor importance. The key claims in Abortion and Original Meaning, he might say, are not empirical but conceptual or normative. They concern, not how many originalists presently endorse expectation originalism, but what follows once we reject it.

I agree that this is the claim of importance. Nonetheless, the attention I have given Balkin's empirical contentions is still warranted. For one thing, a surprising number of other smart and careful scholars appear to believe, just as Balkin does, that expectation originalism enjoys vibrant support. ${ }^{34}$ It seems plausible to suppose that a sedulous effort (which I do not claim to have undertaken) to confirm or falsify this assumption might have some effect on how the debate over originalism will continue to unfold. Furthermore, and of more particular present relevance, readers who agree that almost nobody of any seriousness accepts expectation originalism should recognize as well that almost everybody even among the originalists appreciates that correct applications of the constitutional meaning can change over time. Indeed, McConnell insisted on precisely this a decade ago. ${ }^{35}$ So if living constitutionalism is merely the view that correct applications of constitutional meaning can change over time-i.e., that conduct constitutional at time $t_{1}$ can become unconstitutional at $t_{2}$ (or vice versa) - then, sure, originalism embraces living constitutionalism. But the near-universal assumption is that living constitutionalism accommodates diachronic change different in character and magnitude from what originalism permits. I assume that it is this contention that Balkin aims to deny when averring that originalism and living constitutionalism present "a false choice." And if that is his object, it must be accomplished not by his rejection of expectation originalism but by his affirma-

34. See, e.g., KeRmit RoOsevelt III, THE MYTH OF JUdicial ACTIVISM 47-58 (2006); Aileen Kavanagh, Original Intention, Enacted Text, and Constitutional Interpretation, 47 AM. J. JURIS. 255, 265 (2002).

35. See McConnell, supra note 15; see also, e.g., Lessig, supra note 29, at 396. 
tion of what he calls "the method of text and principle." ${ }^{36}$ So if Balkin's "false choice" claim is itself false, it will not be because originalists reject his method of text and principle but because living constitutionalists do. ${ }^{37}$ One important upshot of the argument in Section I.A, then, is to underscore that the readers he must seek to persuade are not the originalists but their opponents.

The remainder of this Part argues: that living constitutionalists do reject Balkin's method; that Balkin provides no argument for why they ought not to reject it; and that, to the contrary, much of Balkin's focus on extrajudicial constitutional interpretation and the role of social movements (a rightful and illuminating focus, in my view) should lead him to join the living constitutionalists in rejecting the method of text and principle that he advocates.

\section{1.}

What reason could anyone have for rejecting the method of text and principle? Could it really be that constitutional interpretation does not "require[] fidelity to the original meaning of the Constitution and to the principles that underlie the text"? Much depends, I think, on what is meant by the recurring and ambiguous phrase: "the principles that underlie the text."

Taken in isolation, the phrase permits at least two distinct interpretations: the principles that, in a Dworkinian vein, make best sense of the text or show it in its morally best light; or the principles that in actual historical fact were intended by the framers, or understood by the ratifiers, to be captured by the

36. Balkin, supra note 1 , at 293.

37. A note on terminology: In my opinion, the negation of originalism is more felicitously rendered not as living constitutionalism but as non-originalism. Very briefly, I take originalism to be the view that some specified class of constitutional interpreters (paradigmatically judges. but, on some accounts, everybody) owes a strict obligation of fidelity to some aspect of the Constitution's original character-that the interpreters must always follow the original object, at least when it is adequately discoverable. The negation of this view-i.e.. the claim that it is not the case that interpreters owe strict fidelity to the specified aspect of the Constitution's original character-would be. simply, non-originalism. In arguing that, over at least some range of cases, interpreters ought to abandon original meaning (intent, understanding, principles, or what-have-you) in favor of contemporary meanings or values, living constitutionalism comprises a subset of nonoriginalism but is not entailed by it. In any event, as the distinction I favor between nonoriginalism and living constitutionalism is not essential to a diagnosis of what I take to be unsatisfactory in Balkin's account. I follow him in contrasting originalism to living constitutionalism. 
chosen text. ${ }^{38}$ In fact, though, Balkin makes adequately clear that he means the latter, not the former. What we are searching for, he explains, are "the general principles that animated the text" ${ }^{39}$ - those that the people who drafted the text "sought to endorse," "sought to refer to," or "sought to establish." Balkin's method of text and principle, we might say, is a method of text and original principle. Living constitutionalists, in contrast, might be thought to employ a method of text and evolving or contemporary principle.

To appreciate the difference, consider any constitutional provision, $\mathrm{T}$, that is most appropriately read as referring to a moral principle, not just to a legal rule or even a standard. Now suppose that $\mathrm{T}$ is sufficiently vague or ambiguous to accommodate or refer to two (or more) distinct moral principles, $\mathrm{P}_{1}$ and $P_{2}$. Finally, imagine that an interpreter is convinced that $P_{1}$ is the superior moral principle, both by her own lights and by the lights of a substantial majority of the contemporary populace, yet that, according to the best historical evidence, the framers and ratifiers of T sought to refer to $P_{2}$. The question is whether our interpreter's obligation of fidelity to the Constitution entails an obligation to adopt $\mathrm{P}_{2}$ as her constitutional interpretation-as her understanding, that is, of what the Constitution means. Balkin's method of text and original principle seems to answer that she does. The living constitutionalist's interpretive method (or at least a possible method of living constitutionalism) answers that she does not.

This abstract problematic can be made more concrete. Consider, to start, the Free Exercise Clause. Whereas the framers might have sought thereby to endorse the principle that all religious believers ought to be entitled to worship as they choose, we might now pay more allegiance to the kindred-but distinct-moral principle that all persons, believers, agnostics and atheists alike, should be entitled to worship, or not, as they choose. The Free Speech Clause might have been drafted and ratified to endorse a principle related to democratic self-

38. Underlie means "to be the support or basis of." AMERICAN HERITAGE DICTIONARY 1318 (2d ed. 1982); WEBSTER's THIRD NEW INTERNATIONAL DICTIONARY 2489 (Philip Babcock Grove ed., 1993) ("to be at the basis of: form the foundation of: support"). A principle could provide moral support for the text in the sense of justifying our contemporary obedience to it, or respect for it; or it could provide causal support in the sense of explaining why the text was adopted.

39. Balkin. supra note 1, at 302 (emphasis added).

40. Id. at 303, 319 . 
governance; today, perhaps, we understand it to embody a principle of individual self-realization. The framers and ratifiers of the Self-Incrimination Clause might have aimed merely to outlaw a particular historical practice and not to refer to a moral principle at all; today, perhaps, we understand it to endorse a principle of human dignity.

While examples of this sort could be multiplied, ${ }^{41}$ we might finish by returning to our previous discussion of Bork's flimsy defense of Brown. The defense seems lame precisely because we do not think that equality, simpliciter, is an accurate rendering of the principle that the framers and ratifiers of the Fourteenth Amendment actually sought to endorse. We believe that the animating principle was more determinate than that-civil equality, or formal equality, or anti-subordination, or equal regard, or color-blindness, etc. Living constitutionalists would permit interpreters to eschew whatever equality-type principle the framers and ratifiers actually "sought to endorse" in favor of the equality-type principle-a principle, mind you, that the text can bear-that better suits our contemporary needs and moral values.

Balkin is far from the first scholar to conclude that a focus on constitutional principles effaces the originalism/nonoriginalism distinction. ${ }^{42}$ But because an approach of the sort just sketched plainly allows for greater flexibility of bottom-line result than does the Balkinian approach that permits interpreters to argue only about different applications of the originally intended principle, it seems to follow that originalism and living constitutionalism continue to offer a true, rather than false, choice.

41. Keep in mind that these examples are offered only to further illustrate how living constitutionalism could differ from Balkin's method of text and original principle. For this limited purpose. lengthy argument about the relevant history is quite beside the point. I assume that it is similarly unnecessary at this stage to elaborate on a theory of how to individuate moral principles.

42. See, e.g., Segall, supra note 16. at 432-33 ("Once strict originalism [i.e., expectation originalism] is taken off the table, and it has been off the table for a long time. there are no stakes left to arguing about the originalism question. ... Th[e] move from specific intentions to general principles... eliminates any meaningful distinction between originalism and non-originalism because the Constitution's broad phrases are defined at a level of generality that make them useless in hard cases for anything other than symbolic purposes."); Lawrence B. Solum, Originalism as Transformative Politics, 63 TUL. L. REV. 1599, 1612-13 (1989); ROOSEVELT, supra note 34, at 47-58 (arguing that the importance of the originalism/living constitutionalism debate "is drastically overstated," but starting, like Balkin. from what I have argued is the mistaken premise that "living constitutionalists and originalists share th[e] assumption" that originalism prescribes fidelity to originally expected applications). 
2.

To conclude that the "false choice" thesis is itself false is not yet, of course, to suggest that the alternatives are equally attractive or even that the method favored by living constitutionalism ought to be considered truly eligible. Perhaps, that is, living constitutionalism offers no true choice as against originalism not because it directs interpreters to act just as originalism, properly understood, does, but because the competing direction it provides cannot be defended. Unfortunately, Abortion and Original Meaning does not appear to develop any arguments to that effect. Instead, Balkin treats the proposition that constitutional interpretation requires "fidelity to the words of the text, understood in terms of their original meaning, and to the principles that [originally] underlie the text" as an essentially undefended "premise" or "assumption."

Addressing all the arguments that have been provided elsewhere against living constitutionalism would require a paper of its own. Here, I can offer only a much-condensed sketch of why Balkin's own trenchant analysis of social movements suggests that his proposed method of text and original principle is actually less faithful to our practice, and less attractive, than is the living constitutionalists' method of, let us say, text and evolving principle.

The basic tension in Balkin's account arises from his privileging of extra-judicial constitutional interpretation. "Theories of constitutional interpretation," he says, "should start with interpretation by citizens as the standard case." ments in particular serve as principal drivers of constitutional understandings, "constitutional culture," and "constitutional doctrine." maintaining fidelity to the past. "Restoration" and "redemption" might be their "key tropes," 46 but we should not confuse rhetoric with reality. The truth is that citizens, social movements, and political parties do more than argue about "how best to apply" originally intended constitutional principles in contemporary circumstances. ${ }^{47}$ They argue as well about what the constitutional principles are-which is why those who would challenge a given

43. Balkin. supra note 1, at 294-95. 302.

44. Id. at 307 .

45. Id. at 308 .

46. Id. at 301 .

47. E.g., id. at 293. 
movement's agenda often argue not that it applies the originally understood principle incorrectly, but that the principle it pushes is not of constitutional stature at all. This, for example, is how the defenders of affirmative action respond to the living constitutionalists (masquerading as crusaders for originalism, as living constitutionalists frequently do) who champion a constitutional principle of color-blindness.

And if a movement prevails in persuading the general public to accept the principle it puts forth as a constitutional one? Well, as far as I can tell, Balkin provides no reason why judicial interpretation should not follow suit, least of all that judicial resistance to a successful extrajudicial interpretation not predicated on historical fidelity is categorically mandated. To the contrary, that judicial interpretation may follow and endorse nonoriginalist but popularly accepted constitutional interpretations is, I take it, at least part of what it means for judicial interpretation to be "parasitic" upon extrajudicial interpretation. ${ }^{48}$ No doubt one could maintain that courts must refuse to sanction the new extrajudicial understanding of constitutional principle that the successful social movement has wrought on the grounds that that understanding lacks historical fidelity and therefore legitimacy. But such an attitude would, I think, rest on either a bizarre misconception of what social movements are for-they serve, after all, as advocates for a vision of the political good, not as historians - or an unrealistic sense of how long courts might (or should) stand against successful popular mobilizations. It's hard to see Jack Balkin falling into either error. ${ }^{19}$

48. Id. at 307. Incidentally. I am in substantial agreement with Balkin's ruminations about the relationship between constitutional doctrine and constitutional interpretation-most notably the idea, see, e.g., id. at 307. 314-15. that judge-announced constitutional doctrine serves to implement. and is therefore not identical to. judicial interpretations of constitutional meaning. See, e.g., Mitchell N. Berman. Constitutional Decision Rules, 90 VA. L. REV. 1 (2004); Mitchell N. Berman. Aspirational Rights and the TwoOutput Thesis, 119 HARV. L. REV. F. 220 (2006), http:/www.harvardlawreview.org/forum/ issues/119/march06/berman.pdf. I am very skeptical, though, that a proper understanding of this distinction will provide any avenue of escape from the conclusion in the text.

49. See, e.g., Jack M. Balkin, Roe v. Wade: An Engine of Controversy, in WHAT RoE V. WADE SHOUld Have SaID 3. 23-24 (Jack M. Balkin ed. 2005) ("[C]ourts, whether they like it or not, always work in conversation with the political branches in developing constitutional norms... . The work of courts. important as it may be. is always an intermediate and intermediary feature of a much longer process of legal development that stretches back into the past and forward into the future."). 


\section{ABORTION}

Even if the larger ambition of Abortion and Original Meaning is to reshape debates over constitutional interpretation generally, the greater bulk of the piece explores the original meaning of the Fourteenth Amendment and draws forth implications for the abortion debate. In the smallest of nutshells, Balkin argues that the various clauses of section 1 of that amendment were intended to constitutionalize, among other things, a principle of equal citizenship and a prohibition on class legislation. Laws that criminalize even first-trimester abortion violate these principles, and are therefore unconstitutional, even though the framers and ratifiers of the Fourteenth Amendment might not have so realized.

This is deeply interesting stuff, though I am insufficiently knowledgeable of the relevant history and secondary literature to assess it very intelligently. My principal critical reaction, however, is to question whether Balkin's historical and interpretive claims are either necessary or sufficient to support the holding in Roe.

The ordinary, perhaps inescapable, path toward justifying the conclusion that legislative prohibitions on early-stage abortions are unconstitutional consists of two steps: Establishing, first, that prohibitions on early stage abortions require weighty justification; and second, that the state's interest in protecting the life, and opportunity for birth, of the unborn fetus does not supply a justification of requisite weight. Of the two, the first is much the easier.

Balkin's argument is geared principally to tackling that first task - that is, to establishing that there exists a constitutional right to choose an abortion. ${ }^{8}$ But even granting its plausibility, I confess to thinking that the more usual move, of the sort hinted at in Roe and developed somewhat further in Casey, is adequate too. Roughly, and without elaboration or defense, I take that argument to be: (1) that various constitutional clauses - the Privilege or Immunities Clause, the Due Process Clauses, and the Ninth Amendment among them-are appropriately interpreted to provide heightened protection for liberty interests of special importance to the individual's prospects for realizing a life of meaning and fulfillment; and (2) that a pregnant woman's inter-

50. Actually, he argues provocatively that there exist two distinct constitutional rights to abortion. For purposes of my concern, however, we can put that wrinkle aside. 
est in terminating her pregnancy qualifies as an interest of precisely this sort. In short, then, I think that Balkin's analysis is very possibly adequate, but not necessary, to the first step on the path to the conclusion that abortion prohibitions are unconstitutional.

In any event, this is, as I have said, the easier step. ${ }^{51}$ The more challenging one is to establish that protection of the unborn does not provide the justification needed-that prohibitions on abortion do not merely implicate or infringe a constitutional right to choose an abortion, but violate it. On this score, however, Balkin offers very little. To be sure, he does argue that a fetus is not properly understood as a person within the meaning of the Due Process and Equal Protection Clauses. ${ }^{52}$ And I fully agree. But I think that most abortion opponents do too. Unfortunately, this conclusion does not get Balkin where he needs to go, for the compelling interests that a state might pursue are not limited to the protection of constitutional persons. If fetuses are persons in the morally relevant sense, or if they are moral rights-bearing entities, then it seems likely, perhaps obvious, that the state's interest in protecting them should suffice to justify infringements on the constitutional rights of pregnant women. Some response to this objection is required, I should think, to justify the result in Roe. Because I do not think Balkin supplies an adequate response in this paper-indeed, it is not clear to me that he supplies any response at all-I conclude that his analysis of abortion, while surely of interest, is neither necessary nor sufficient to establish that the state may not criminalize first-trimester abortions.

The great oddity is that, elsewhere, Balkin did expressly recognize the need for supporters of the Roe result to go beyond the "fetuses are not constitutional persons" argument. In the mock opinion he produced for his edited volume, What Roe v. Wade Should Have Said: The Nation's Top Legal Experts Rewrite America's Most Controversial Decision, Balkin (writing

51. Critics of the abortion right often seem to view the diversity of arguments advanced to ground the right as evidence of the proponents' result-orientedness. even of their moral or intellectual bankruptcy. I see it. instead, as largely a consequence of scholars' efforts (perhaps unnecessary, but sincerely felt) to identify textual homes for a right that is more forthrightly derived by structural reasoning. When one thinks. not of bits of text viewed piecemeal, but of the Constitution's broad and deep commitment to principles of individual liberty and equality. the conclusion that legislative prohibitions of abortion cannot stand unless supported by weighty justification strikes me as wholly overdetermined.

52. Balkin, supra note 1 , at 333-337. 
then as Chief Justice Balkin) reasoned that the precise contours of most abortion laws-most notably, the exceptions they frequently grant for pregnancies produced as a result of rape or incest and their total exemption from criminal liability of the pregnant woman herself-undermine the regulating states' contentions that they genuinely ascribe moral personhood to the nonviable fetus. ${ }^{53}$ This is a not-uncommon argumentative strategy, ${ }^{54}$ and one with which I have considerable sympathy.

In skeletal form, the version of the argument that I favor rests on the notion that all laws reflect a balancing of interests and that a law prohibiting abortion could reflect two very different types of balancing. To oversimplify, the law could issue from a recognition that the costs that the law imposes on women is very substantial, but that the benefits (in terms of protection of an entity with a moral status equivalent, or roughly equivalent, to persons already born) are even greater. Alternatively, it could be based on a judgment that fetuses do not have the moral status of persons, and therefore that the state's interests in prohibiting abortion (interests that can include, but need not be limited to, the protection of potential life) fall rather short of compelling, but that interests of such weight nonetheless outweigh the countervailing liberty interests of women. In shorthand, we might say that the law could be understood by its drafters and proponents as either high-cost/higher-benefit or low-cost/medium-benefit.

Now, if the judiciary were in a position to conclude that a nonviable fetus does, or does not, have the moral status akin to a neonate, then the understanding about the moral status of the fetus held by the state (so to speak) would be, I think, neither here nor there. If a nonviable fetus lacks substantial moral status, then prohibitions on early-stage abortion do not serve a compelling interest regardless of what the state believes. Similarly (though possibly not quite as obviously), if the nonviable fetus does have substantial moral status, then early-stage abortion bans do serve a compelling interest even if the state thinks that they don't. But the judiciary is not positioned to make either such conclusion. And that's why the state legislature's actual beliefs about the moral status of the fetus become critical.

53. Jack M. Balkin. (judgment of the Court). in WHAT ROE V. WADE SHOULD HAVE SAID. supra note 49, at 31, 47-52.

54. See, e.g., RoOsEVELT, supra note 34, at 118-30: Guido Calabresi. The Supreme Court, 1990 Term-Foreword: Antidiscrimination and Constitutional Accountability: What the Bork-Brennan Debate Ignores, 105 HARV. L. REV. 80 (1991). 
It follows that the question for a judiciary that has determined that the liberty interests of women are constitutionally entitled to great weight, is whether to accept the state's representation that its restrictions on abortion in fact issue from an assessment of the first sort and not of the second. To put the point differently, the state has a compelling interest in protecting against destruction of beings that it reasonably believes have a moral status equivalent to, or close to, that of a neonate. So in this unusual case, the judicial question of whether the state's interest is compelling is parasitic upon what the state actually believes about the nature of the thing that it is endeavoring to protect. But the state has reasons to misrepresent (to the courts, perhaps even to itself) what its actual beliefs are. So the courts ought not to simply accept without question the state's representations as to its actual beliefs. To do so would be to substantially under-protect the abortion right. How the courts ought to proceed in general-including what inference the Supreme Court should have drawn about the Texas law in 1973, and what inferences it should draw about the beliefs that have motivated other abortion laws at other times-are questions that I cannot address here, except to note my conviction that the skeptical inference is sometimes, perhaps often, appropriate.

That no argument of this form appears in Abortion and Original Meaning is conspicuous and, therefore, most intriguing. Perhaps it is simple oversight. Or perhaps Balkin has now discerned failings in the argument that had not previously occurred to him. Either way, I think we need to hear more about why bans on first-trimester abortions cannot justifiably infringe the abortion right (even assuming that nonviable fetuses are not, constitutionally speaking, persons) before we can conclude, with Balkin, that such bans are unconstitutional.

\section{CONCLUSION}

The debate over originalism concerns whether constitutional interpretation must be a search for the original understanding (or intent, or meaning, or the like). It is a debate over whether the correct meaning of the Constitution-and not just its case-specific applications-can change from $t$ to $t_{1}$ even absent constitutional amendment. It seems to me that there can be only two answers to this question--"yes" and "no"-and that they conflict. The analysis that would show these answers to pre- 
sent "a false choice" or to be "opposite sides of the same coin" 55 is not, I predict, in the cards.

My answer to this central question - an answer that, admittedly, I have not defended here-is affirmative. That makes me a non-originalist. It seems to me that Balkin's privileging of constitutional interpretation by social movements (which are compelled neither by logic nor by political morality to maintain historical fidelity), over interpretation by judges, ought to lead him to answer that question in the affirmative as well. But perhaps I'm mistaken. Perhaps Balkin really is an originalist. If so, I would be eager to see his reasons for concluding that the originalist answer is better than the non-originalist answer, rather than that the two answers are one.

$$
* * *
$$

In his reply to his commentators, ${ }^{56}$ Balkin treats my own contribution with seriousness, respect, and care. Unfortunately, much of what he says about my analysis causes me to conclude that I have not succeeded in making myself entirely clear. Some response is therefore warranted. Given the length and comprehensiveness of that reply, there are a large number of claims to which I'd like to respond. But I will limit myself to trying to make two points. First, I will restate my core criticism of Balkin's thesis and explain why I believe that it survives the arguments that Balkin musters in his reply. Second, I will briefly address some of the respects in which Balkin's analysis suggests a misunderstanding of what I have attempted to convey.

\section{Balkin's "false choice" claim is false}

Although Abortion and Original Meaning is rich in arguments, I understand it to advance two core claims - a normative claim about how the Constitution ought to be interpreted, and something close to a conceptual claim about the range of possible alternatives to the normative question. The former is his proposed method of text and principle (which I will call TP), and the latter is his claim that originalism and living constitutionalism present a false choice (which I will call FC). Stated slightly more formally, the claims are these:

55. Balkin, supra note 1 , at 348 .

56. Jack M. Balkin, Original Meaning and Constitutional Redemption, 24 CONST. COMMENT. 427 (2007). 
TP: "Constitutional interpretation requires fidelity to the original meaning of the Constitution and to the principles that underlie the text." ${ }^{, 57}$

FC: There is no difference between originalism and living constitutionalism because both theories can and should affirm TP.

My central point has been that Balkin's "false choice" claim is incorrect: there is a real choice between originalism and living constitutionalism. Balkin's argument to the contrary commits the fallacy of equivocation. Here, in a condensed presentation, is how I take my argument to run:

(1) A given text can, and at least some provisions of the U.S. Constitution do, bear the meaning of more than one moral principle, i.e., more than one moral principle can be attributed to the same constitutional text.

(2) Therefore, "the principles that underlie the text" is ambiguous. It can refer to (at least): (a) the principles that the framers or ratifiers actually sought to constitutionalize by means of the chosen text, or (b) the moral principles that fit the text and that, from the interpreter's perspective, best justify our continued obedience to it.

(3) By substitution, TP comes in at least two variants: (a) constitutional interpretation requires fidelity to the original meaning of the Constitution and to the principles that the framers or ratifiers actually sought to constitutionalize by means of the chosen text; and (b) constitutional interpretation requires fidelity to the original meaning of the Constitution and to the principles that fit the text and that, from the interpreter's perspective, best justify our continued obedience to it.

(4) Originalism is committed to (a), so call it TP-O; at least some Living Constitutionalists endorse (b), so call it TP-L.

(5) TP-O and TP-L are functionally non-equivalent: When employed in constitutional argument, they will

57. Balkin, supra note 1, at 293; See also Balkin, supra note 56. at 428 ("I argue that fidelity to the Constitution means fidelity to the original meaning of the Constitution's text and to the principles that underlie the text."). 
not produce identical sets of "interpretations of the Constitution" or of specific constitutional holdings.

(6) Therefore, FC is false. There is a difference between originalism and living constitutionalism because the former and the latter do not endorse variants of TP that are the same or functionally equivalent.

In the course of my comment, I expressed the view (which I was not alone in holding) ${ }^{58}$ that Balkin himself espouses TP-O. I marshaled evidence for this conclusion from various passages in Abortion and Original Meaning. ${ }^{59}$ Balkin addresses this claim at some length in his reply. ${ }^{60}$ Suffice it to say, that I now think (but confess to not being entirely certain) that I got him wrong, that he does not really mean that interpreters owe fidelity to the principles that the ratifiers sought to endorse, but only that they owe fidelity to the principles that the text that the ratifiers did endorse can bear. As Balkin says, "the key issue is ... that constitutional principles must be ones 'that the text can bear." ${ }^{\prime \prime 1}$ In any event, which view Balkin himself holds is not important to my argument. The critical point is only that these two positions exist and that they are not equivalent.

But is that claim mistaken? Balkin challenges some of the examples I put forth to illustrate my premise (1). In fact, I believe that my particular illustrations survive his challenge. But no matter. My illustrations were purely illustrative. Even if Balkin and I end up disagreeing abut individual cases, I see nothing in his reply that should lead one to question that at least some of the constitutional text is sufficiently ambiguous to mean or refer to more than one principle of political morality. To be sure, he intimates that (1) depends upon the erroneous assumption that the principles underlying the constitutional text "will have to be stated at a fairly low level of generality.",62 But I did not take myself to be making any such assumption and, yet more importantly, the premise doesn't depend upon it. I see nothing else in Balkin's reply that would cause trouble for my argument. And because (2) and (3) follow straightforwardly from (1), and because (4) and (5) would seem uncontroversial given (3), I believe that my challenge to FC remains sound.

58. See Ethan Leib. The Perpetual Anxiety of Living Constitutionalism, 24 CONST. COMMENT. 353, 354-56 (2007).

59. See supra notes $39-40$ and accompanying text.

60. Balkin, supra note 56 , at 487-519.

61. Id. at 488 .

62. Id. at 487 . 


\section{The method of text and principle}

Balkin expends considerable energy elaborating the method of text and principle, and defending it against attacks from his critics. I am supposed to be one of those critics. Thus, for example, I am said to object both "that political and social movements do not use the method of text and principle," and "that it is dangerous to adopt a constitutional theory that incorporates and justifies the work of political and social movements. ${ }^{.63}$ I do not in fact believe either of those things, and I am disheartened to learn that my text has betrayed me so badly.

Of course political and social movements use the method of text and principle (or something like it). ${ }^{64}$ What else would they use? The question is which method of text and principle-TP-O or TP-L? Probably both, I suppose. But given their aims (which Balkin describes in rich historical detail and with eloquence) and their lack of training in historical methods, I conclude that they mostly employ TP-L. I don't know what in my paper invited the conclusion that I believe that social movements "often make claims based on simple policy grounds." ${ }^{.65}$ And when I suggested we can't trust their rhetoric, I meant only that we cannot blithely accept whatever claims they might sometimes make to be employing TP-O, not that their "arguments for restoration and redemption [are] nothing more than rhetorical tropes." ${ }^{.66}$

Far from believing that a theory that justifies the work of political and social movements is dangerous, my claim is closer to the opposite. I believe that the account of the evolution of constitutional meaning that Balkin describes and champions in his reply is largely descriptively accurate, largely normatively attractive, and at least partly inescapable for a polity constituted as ours is. The point of my remarks in Section I.B.2 was to chal-

63. Id. at 504: see also id. at 512-13.

64. The parenthetical in the text is necessitated by my belief that social movements (as well as judges or individual citizens. for that matter) are not rigidly bound by the original meaning of textual provisions that state something other than principles. But this is not the place to elaborate that particular view.

65. Balkin, supra note 56, at 504.

66. Id. at 507 (emphasis added). Admittedly. I probably invited that misunderstanding by contending that "social movements do not view their task as maintaining fidelity to the past." Supra at 394 . I'm confident that's not what they view as their principal task. Their principal task is forward-looking. But in pursuing their forward-looking goals. I agree that they frequently feel themselves to be maintaining fidelity to at least an imagined past. In short. the truth is more nuanced than my very brief remarks might have suggested. 
lenge TP-O by suggesting that it does not take social movements seriously enough. The conclusion rests on three premises.

First, as just discussed, social movements employ TP-L to a significant extent. Second, the constitutional understandings that arise by application of TP-L can secure widespread popular endorsement or can underwrite stable governmental practices that depart from what TP-O would authorize. Third, when that happens, it is at least sometimes appropriate for judicial constitutional interpretation to track TP-L rather than TP-O. Therefore, TP-O cannot be correct as a complete or total account even of how courts ought to perform their role in our scheme of constitutional governance.

67. I have not provided much argument for the critical third premise beyond my brief remarks in the final paragraph of Section I.B.2. including my observation that "Balkin provides no reason [against it]." Supra at 395. If Balkin now recognizes that TP$\mathrm{O}$ and TP-L are not identical and endorses the latter, then I'd suppose that he accepts the third premise. But an argument to the contrary might possibly be grounded in Balkin's remarks about the value of "preserv[ing] legal meaning over time." Balkin, supra note 1, at 429 . Surely the preservation of legal meaning across time is a desideratum of a legal system. But I do not take Balkin to be contending that it is a conclusive demand of logic or political morality. That, I think, would be quite mistaken. 